\title{
Reasons for Prophylactic Mastectomy in Women Carrying BRCA 1/2 Mutation: A Systematic Literature Review
}

\author{
Manuel Machado, Sofia Braga* \\ Departamento de Ciências Biomédicas e Medicina da, Universidade do Algarve, Pr. Heróis da Fundação, Guimarães, Portugal \\ Email: manuelsmachado@yahoo.com, *sofia.braga@jmellosaude.pt
}

Received March 26, 2013; revised April 28, 2013; accepted May 7, 2013

Copyright (C) 2013 Manuel Machado, Sofia Braga. This is an open access article distributed under the Creative Commons Attribution License, which permits unrestricted use, distribution, and reproduction in any medium, provided the original work is properly cited.

\begin{abstract}
Although the majority of breast cancers are sporadic, it is estimated that between $5 \%$ and $10 \%$ of cases are hereditary and mostly associated with BRCA 1 and BRCA 2 mutations. Women with BRCA 1 or BRCA 2 mutation present up to 95\% increased risk of breast cancer and are advised to take preventive measures. Surveillance, chemoprevention and prophylactic surgery (mastectomy and oophorectomy) are risk-reducing strategies. This literature review aims to respond to two major questions: 1) to what extent is the decision-making for prophylactic mastectomy in women with the BRCA mutation a more relevant option than other strategies, and 2) what are the major factors influencing the decision for mastectomy? For this purpose, 27 published articles were reviewed. Results show: a) the decision for mastectomy is more frequent in women carrying BRCA $1 / 2$ mutation than in non-carriers; mastectomy being less frequent than oophorectomy; b) the decision-making is significantly associated with BRCA mutation, parity, age and family history; c) reasons underlying women decision-making relate to anxiety toward the risk of cancer, concerns with surgery, body-image and sexuality. It is discussed that, due to the complexity of the decision-making process, these cases require a careful and meticulous approach regarding information provided, and in addressing concerns.
\end{abstract}

Keywords: BRCA 1; BRCA 2; Prophylactic Mastectomy; Decision Making

\section{Introduction}

Breast cancer is the second most commonly diagnosed cancer in women and a major cause of cancer-related mortality [1]. The majority of breast cancers are sporadic, i.e., occur in women with no family history of cancer. About $70 \%$ to $80 \%$ of breast cancers are placed in this category [2]. However, it is estimated that $5 \%$ to $10 \%$ of cases have hereditary causes and, in women under 35 years of age, this percentage ascents to $25 \%$ to $40 \%$ [2].

Although several genes have been associated with hereditary types of cancer, the majority of cases of breast and gynecological cancer (ovaries, fallopian tubes, and peritoneum) in which a family history of cancer is present are associated with mutations in BRCA 1 and BRCA 2 genes. It is estimated that $60 \%$ to $70 \%$ of hereditary cancer cases are related with mutations in these genes [3]. These genes were identified in the mid $1990 \mathrm{~s}$ and are classified as tumor suppressor genes BRCA 1 and BRCA 2 [4,5]. Both have high-level coding sequences, consisting of 51 exons in total, with the majority of mutations

*Corresponding author. described as protein-truncating mutations, containing frameshift mutations [6].

Mutations in BRCA 1 are more associated with the basal or triple negative subtype of breast cancer with predominance of lymphocytic infiltration with histologically aggressive features [7]. Moreover, tumors associated with mutations in BRCA 2 tend to be luminal, estrogen receptor positive and progesterone receptor positive [7]. There remained controversy regarding prognosis of BRCA-associated breast cancers but Rennert et al. [8] found no differences in breast cancer-specific rates of death among Israeli women with BRCA founder mutation and noncarriers.

Germ line mutations in BRCA 1/2 are related with higher risk for breast and ovarian cancer in women, when compared to general population. However, the magnitude of risk is very wide and often contradictory, as it also depends on contextual factors (family history, ethnicity, environmental, hormonal and lifestyle factors). Results from a meta-analysis show that, in women with a BRCA1 mutation, the average cumulative risk of cancer at the age of 70 years is $57 \%$ (95\% CI 47 - 66) and, for women with a 
BRCA 2 mutation, it is of 49\% (95 CI 40\% - 57\%) [9]. However, Bermejo-Perez et al. [10] indicate that, in women with BRCA1 mutation, the average risk of cumulative breast cancer at the age of 70 years ranges from $51 \%$ to $95 \%$ and for BRCA 2 mutation, the risk ranges between $33 \%$ and $95 \%$. The greater penetrance was found in families with multiple cases of cancer.

Clinically, breast cancers associated with mutations of the genes BRCA 1 and BRCA 2 seem to have an earlier onset, when compared with sporadic breast cancer. The average age of breast cancer onset is at 40 to 50 years for BRCA 1/2 mutation carriers, and at 60 to 70 years for sporadic cases [11]. BRCA 1 mutation seems to be associated with earlier onset breast cancer, when compared with BRCA 2 mutations [12].

Women at high-risk for breast cancer, such as the carriers of BRCA 1/2 mutations, are advised to take preventive measures in order to reduce risk. Currently, there are various medical and surgical options for the prevention of breast cancer, namely: intensive monitoring, chemoprevention and prophylactic surgery, which can be divided into mastectomy and oophorectomy. The National Comprehensive Cancer Network [14] has established screening and intervention guidelines (NCCN guidelines) for hereditary breast and/or ovarian cancer syndrome (associated with BRCA 1/2 mutations), which include the three afore mentioned options (http://www.nccn.org). There are other hereditary syndromes, which are less frequent, such as the Li-Fraumeni (associated with TP 53 mutations), the Cowden (associated with PTEN gene mutations), or the Peutz-Jeghers syndrome (associated with STK 11 mutations), for which the NCCN also established specific guidelines. However, these syndromes are not under the scope of this study.

The efficacy of these interventions varies, and to perform a linear meta-analysis is not a simple process. This happens because of the type of studies conducted and included in the analysis (which are difficult to operationalize as randomized-control studies), as well as because of the difficulty in defining specific criteria to evaluate the overall effectiveness of each strategy studied. Review studies show that there is a higher effectiveness of prophylactic surgery strategies compared to other strategies, in women carrying BRCA mutations [7,10,12]. Regarding prophylactic surgery, and more specifically in relation to bilateral mastectomy, there seems to be a reduction of risk for breast cancer in $85 \%$ to $100 \%$, in carriers of BRCA mutations [7,12]. In the case of oophorectomy, it reduces the risk of ovarian cancer in $96 \%$, and of breast cancer in 53\%. Nevertheless, there are adverse events inherent to these interventions that need to be taken into account. In fact, Bermejo-Pérez and colleagues [10] found between $21 \%$ to $30 \%$ prevalence of mastectomy complications including hematomas, infections, contractions or rupture of the implant in cases of immediate reconstruction. Surgical interventions may also present additional complications with respect to psychological issues, particularly regarding body image, and mother and wife roles [10].

The surveillance strategies are based on early detection of cancer and not on prevention, which is difficult to study in comparison studies. The mammogram seems to present lower sensitivity results in women with BRCA mutation (40\% to 56\%) [10], but this sensitivity seems to increase (83\% to 95\%) with the combination of MRI $[7,10]$.

The decision for chemoprevention is based on the assumption that oestrogen plays a major role in carcinogenesis [13-15], and based on this assumption, tamoxifen, may prevent of breast cancer and ovarian cancer $[7,10$, 12]. In a clinical trial, tamoxifen reduced the risk of invasive breast cancer, but significant reduction was found only in ER-Positive tumours, [16]. Although data for tamoxifen as an effective strategy to reduce breast cancer are convincing, there are important side effects such as an increase in endometrial cancer, or an increase in vascular events [16]. Other hormonal treatments are being tested as preventive measures for breast cancer, such as the aromatase inhibitors [17].

Surgical mastectomy seems to have a multivariate, complex and often ambivalent nature: recommendations are suggested on a case-by-case basis, and women always have to make the final decision, which is a difficult process. This paper aims to study the decision-making process of women carrying BRCA mutations, regarding the adoption of mastectomy as a risk reduction strategy. To pursue this aim, a descriptive systematic literature review was conducted, in order to respond to the following research questions: 1) to what extent is the decision-making for prophylactic mastectomy in women with the BRCA mutation a more relevant option than other strategies, and 2) what are the major factors influencing the decision for mastectomy? We decided to study the answers to these questions because in medical genetics consultations with women at high familial risk for breast and ovarian cancer we must recommend a prevention strategy and we are frequently confronted with very different decisions from patients regarding the same issue. Therefore, understanding the reasons for accepting or rejecting PM in high risk women has become a highly relevant topic for practical cancer care.

\section{Method}

Research studies conducted between 2005 and 2012 were gathered using electronic databases PubMed and MEDLINE, specifying the following research terms: "BRCA mutation”, "mastectomy" and "prophylactic surgery”. A search for the cited articles in the originally found research studies and reviews was also conducted. 


\subsection{Inclusion and Exclusion Criteria}

In this study, the following inclusion criteria were adopted: original studies, published between 2005 and 2012, in which the participants were women at risk of breast cancer, focusing on the study of the frequency and decision-making process for mastectomy as a prophylactic strategy to reduce the risk of breast and/or ovarian cancer. The following exclusion criteria were defined: 1) Review studies or meta-analysis; 2) Studies that include, as participants, women whose essential right to use their ability to make decisions cannot be fully addressed (children, mentally ill, etc.); 3) Studies in which the majority or the whole sample is comprised by participants with active cancer; 4) Studies in which the sample did not include women carrying BRCA 1 and/or BRCA 2 mutations.

\subsection{Selection of Articles and Data Analysis}

From the first search conducted, 270 articles were found. After screening for repeated articles and applying exclu- sion criteria, 27 papers met the criteria to be included in this review. Regarding data analysis, the general term of Prophylactic Mastectomy (PM) was adopted, including both bilateral and unilateral types, since only one study was found that included a sample with both types of surgery. The other studies included in this review refer to Bilateral Prophylactic Mastectomy, which is the most frequent intervention.

\section{Results}

Table 1 presents the reference for the articles included in this review. Some of these focus on the study of the frequency of prophylactic mastectomy, comparing to other prevention strategies adopted like prophylactic oophorectomy. Other studies aim to explore the factors and processes underlying the decision-making process, either by looking for correlations between factors, either by adopting a more qualitative analysis in describing women's perceptions.

Table 1. Articles selected for the review.

\begin{tabular}{|c|c|c|c|}
\hline Reference & Sample & $\begin{array}{l}\text { Method for data collection follow-up } \\
\text { time frame }\end{array}$ & Issues investigated \\
\hline $\begin{array}{l}\text { Metcalf et al. } \\
\text { (2012) }\end{array}$ & $\begin{array}{l}22 \text { carriers of BRCA } 1 / 2 \\
\text { mutation }\end{array}$ & $\begin{array}{l}\text { Self-completion questionnaire con- } \\
\text { ducted at present time and one year and } \\
\text { two years after genetic testing. }\end{array}$ & $\begin{array}{l}\text { Study of attitudes taken toward risk reduction of } \\
\text { breast cancer. }\end{array}$ \\
\hline $\begin{array}{l}\text { Julian-Reynier et al. } \\
\text { (2011) }\end{array}$ & $\begin{array}{l}101 \text { carriers of BRCA } 1 / 2 \\
\text { mutation } \\
145 \text { non-carriers }\end{array}$ & $\begin{array}{l}\text { Self-completion questionnaire con- } \\
\text { ducted at present time and with a 5-year } \\
\text { follow-up. }\end{array}$ & $\begin{array}{l}\text { Perception and risk reduction strategies of breast } \\
\text { and ovarian cancer. }\end{array}$ \\
\hline $\begin{array}{l}\text { Howard et al. } \\
\text { (2011) }\end{array}$ & $\begin{array}{l}22 \text { carriers of BRCA } 1 / 2 \\
\text { mutation }\end{array}$ & $\begin{array}{l}\text { Interviews analysed based on Grounded } \\
\text { Theory. }\end{array}$ & Perceptions regarding prophylactic surgery. \\
\hline $\begin{array}{l}\text { Rueth et al. } \\
\text { (2011) }\end{array}$ & 71 women with BPM & $\begin{array}{l}\text { Retrospective study of analysis of } \\
\text { medical records. }\end{array}$ & $\begin{array}{l}\text { Characteristics of women who underwent Bilateral } \\
\text { Prophylactic Mastectomy (BPM). }\end{array}$ \\
\hline $\begin{array}{l}\text { Howard et al. } \\
\text { (2010) }\end{array}$ & $\begin{array}{l}22 \text { carriers of BRCA } 1 / 2 \\
\text { mutation }\end{array}$ & Interviews. & $\begin{array}{l}\text { Definition of the right time for decision-making } \\
\text { regarding mastectomy and prophylactic oophorec- } \\
\text { tomy. }\end{array}$ \\
\hline $\begin{array}{l}\text { Kwong et al. } \\
\text { (2010) }\end{array}$ & $\begin{array}{l}31 \text { carriers of BRCA } 1 / 2 \\
\text { mutation }\end{array}$ & $\begin{array}{l}\text { Retrospective study of analysis of } \\
\text { medical records. }\end{array}$ & $\begin{array}{l}\text { Prevalence of breast cancer risk-reduction strate- } \\
\text { gies. }\end{array}$ \\
\hline $\begin{array}{l}\text { Stuckey et al. } \\
\text { (2010) }\end{array}$ & $\begin{array}{l}90 \text { carriers of BRCA } 1 / 2 \\
\text { mutation }\end{array}$ & $\begin{array}{l}\text { Retrospective study of analysis of } \\
\text { medical records. }\end{array}$ & $\begin{array}{l}\text { Characteristics of BRCA mutation carriers who } \\
\text { underwent prophylactic mastectomy, comparing } \\
\text { with those who decided for surveillance. }\end{array}$ \\
\hline $\begin{array}{l}\text { Skytte et al. } \\
\text { (2010) }\end{array}$ & $\begin{array}{l}306 \text { carriers of BRCA } 1 / 2 \\
\text { mutation }\end{array}$ & $\begin{array}{l}\text { Retrospective study of analysis of } \\
\text { medical records. }\end{array}$ & $\begin{array}{l}\text { Prevalence of prophylactic surgery as a breast can- } \\
\text { cer risk reducing strategy. }\end{array}$ \\
\hline $\begin{array}{l}\text { McQuirter et al. } \\
\text { (2010) }\end{array}$ & $\begin{array}{l}10 \text { carriers of BRCA } 1 / 2 \\
\text { mutation }\end{array}$ & Semi-structured interviews. & $\begin{array}{l}\text { Decision-making processes toward Prophylactic } \\
\text { Mastectomy. }\end{array}$ \\
\hline $\begin{array}{l}\text { Landsbergen et al. } \\
\text { (2010) }\end{array}$ & $\begin{array}{l}163 \text { carriers of BRCA } 1 / 2 \\
\text { mutation }\end{array}$ & $\begin{array}{l}\text { Records from genetic counseling } \\
\text { during a 2-year period. }\end{array}$ & $\begin{array}{l}\text { Decision-making processes toward Prophylactic } \\
\text { Mastectomy. }\end{array}$ \\
\hline $\begin{array}{l}\text { Dagan et al. } \\
\text { (2009) }\end{array}$ & $\begin{array}{l}17 \text { carriers of BRCA } 1 / 2 \\
\text { mutation }\end{array}$ & Semi-structured interviews. & $\begin{array}{l}\text { Attributed meaning by BRCA carriers to their con- } \\
\text { dition of high risk for breast and ovarian cancer, as } \\
\text { well as regarding the risk reducing strategies } \\
\text { adopted. }\end{array}$ \\
\hline
\end{tabular}




\section{Continued}

\begin{tabular}{|c|c|c|c|}
\hline $\begin{array}{l}\text { Banckroft et al. } \\
\text { (2009) }\end{array}$ & $\begin{array}{l}373 \text { carriers of BRCA } 1 / 2 \\
\text { mutation }\end{array}$ & $\begin{array}{l}\text { Retrospective study of analysis of } \\
\text { medical records with } 48 \text { months } \\
\text { follow-up. }\end{array}$ & $\begin{array}{l}\text { Prevalence of prophylactic surgery as a breast } \\
\text { cancer risk reducing strategy. }\end{array}$ \\
\hline $\begin{array}{l}\text { Tan et al. } \\
\text { (2009) }\end{array}$ & $\begin{array}{l}73 \text { women recommended } \\
\text { for PM }\end{array}$ & $\begin{array}{l}\text { Records from genetic counseling } \\
\text { during a 30-month period. }\end{array}$ & Factors influencing Prophylactic Mastectomy. \\
\hline $\begin{array}{l}\text { Morgan et al. } \\
\text { (2009) }\end{array}$ & $\begin{array}{l}69 \text { women at risk of } \\
\text { carrying BRCA } 1 / 2 \text { mutation }\end{array}$ & n Telephonic Interviews. & $\begin{array}{l}\text { Prevalence of breast cancer risk reducing } \\
\text { strategies. }\end{array}$ \\
\hline $\begin{array}{l}\text { Litton et al. } \\
\text { (2009) }\end{array}$ & $\begin{array}{l}86 \text { carriers of BRCA } 1 / 2 \\
\text { mutations and } \\
226 \text { non-carriers }\end{array}$ & Self-completion questionnaire. & $\begin{array}{l}\text { Perceptions and ovarian and breast cancer risk } \\
\text { reducing strategies. }\end{array}$ \\
\hline $\begin{array}{l}\text { Staton et al. } \\
\text { (2008) }\end{array}$ & $\begin{array}{l}213 \text { carriers of BRCA } 1 / 2 \\
\text { mutations }\end{array}$ & $\begin{array}{l}\text { Electronic self-completion question- } \\
\text { naire. }\end{array}$ & $\begin{array}{l}\text { Evaluation of decisions concerning evaluation, } \\
\text { prophylactic surgery and family planning. }\end{array}$ \\
\hline $\begin{array}{l}\text { Metcalf et al. } \\
\text { (2008) }\end{array}$ & $\begin{array}{l}517 \text { carriers of BRCA } 1 / 2 \\
\text { mutation ( } 316 \text { BRCA1 and } \\
186 \text { BRCA2) e } \\
186 \text { non-carriers }\end{array}$ & $\begin{array}{l}\text { Questionnaire via e-mail and telephone. } \\
\text { Administered at present time, with } \\
\text { average follow-up of } 4.5 \text { years. }\end{array}$ & $\begin{array}{l}\text { Prevalence of breast cancer risk reducing } \\
\text { strategies. }\end{array}$ \\
\hline $\begin{array}{l}\text { Hoogerbrugge et al. } \\
\text { (2008) }\end{array}$ & $\begin{array}{l}196 \text { carriers of BRCA } 1 / 2 \\
\text { mutation }\end{array}$ & $\begin{array}{l}\text { Non-mentioned. } \\
\text { Average follow-up of } 2 \text { years. }\end{array}$ & $\begin{array}{l}\text { Evaluation of the impact of an abnormal result } \\
\text { of the mammogram or of the MRI in the } \\
\text { decision-making toward Prophylactic Mastectomy. }\end{array}$ \\
\hline $\begin{array}{l}\text { Van Dijk et al. } \\
\text { (2008) }\end{array}$ & $\begin{array}{l}338 \text { women submitted to } \\
\text { BRCA } 1 / 2 \text { test ( } 80 \text { carriers } \\
\text { of BRCA } 1 / 2 \text { mutation } \\
\text { e } 258 \text { non-carriers) }\end{array}$ & $\begin{array}{l}\text { Self-completion questionnaire. } \\
\text { Baseline, } 1 \text { week post BRCA } 1 / 2 \\
\text { testing, } 4 \text { weeks post BRCA } 1 / 2 \\
\text { testing, } 2 \text { weeks, } 3 \text { months and } \\
9 \text { months post disclosure of } \\
\text { BRCA } 1 / 2 \text { test results }\end{array}$ & $\begin{array}{l}\text { Stability of decisions regarding risk-reducing } \\
\text { strategies over time and factors associated with } \\
\text { these preferences. }\end{array}$ \\
\hline $\begin{array}{l}\text { Friebel et al. } \\
\text { (2007) }\end{array}$ & $\begin{array}{l}537 \text { carriers of BRCA } 1 / 2 \\
\text { mutation }\end{array}$ & $\begin{array}{l}\text { Self-completion questionnaire and } \\
\text { retrospective study of analysis of } \\
\text { medical records. Average follow-up } \\
\text { of } 36,9 \text { months. }\end{array}$ & $\begin{array}{l}\text { Prevalence of breast cancer risk reducing } \\
\text { strategies. }\end{array}$ \\
\hline $\begin{array}{l}\text { Antill et al. } \\
\text { (2006) }\end{array}$ & $\begin{array}{l}182 \text { women with high risk } \\
\text { for breast and ovarian } \\
\text { cancer: } 21 \text { carriers of } \\
\text { BRCA } 1 / 2 \text { mutation }\end{array}$ & $\begin{array}{l}\text { Electronic Questionnaire. Average } \\
\text { follow-up of } 3.73 \text { years. }\end{array}$ & $\begin{array}{l}\text { Prevalence of prophylactic surgery as a breast } \\
\text { cancer risk-reducing strategy. }\end{array}$ \\
\hline $\begin{array}{l}\text { Uyei et al. } \\
\text { (2006) }\end{array}$ & $\begin{array}{l}554 \text { women submitted to } \\
\text { BRCA } 1 / 2 \text { test (58 } \\
\text { BRCA } 1 \text { e } 74 \text { BRCA 2) }\end{array}$ & $\begin{array}{l}\text { Retrospective study of analysis of } \\
\text { medical records. }\end{array}$ & $\begin{array}{l}\text { Prevalence of breast and ovarian cancer risk } \\
\text { reducing strategies. }\end{array}$ \\
\hline $\begin{array}{l}\text { Ray et al. } \\
(2005)\end{array}$ & $\begin{array}{l}62 \text { with high risk for breast } \\
\text { cancer and ovarian cancer. }\end{array}$ & Self-completion questionnaire. & $\begin{array}{l}\text { Prevalence of decisions regarding risk-reducing } \\
\text { strategies and factors associated with those } \\
\text { preferences. }\end{array}$ \\
\hline $\begin{array}{l}\text { Metcalf et al. } \\
\text { (2005) }\end{array}$ & $\begin{array}{l}125 \text { carriers of BRCA } 1 / 2 \\
\text { mutation }\end{array}$ & $\begin{array}{l}\text { Self-completion questionnaire via } \\
\text { e-mail. }\end{array}$ & Prevalence of risk-reduction decisions. \\
\hline $\begin{array}{l}\text { Claes et al. } \\
(2005)\end{array}$ & $\begin{array}{l}34 \text { carriers of BRCA } 1 / 2 \\
\text { mutation and } \\
34 \text { non-carriers }\end{array}$ & $\begin{array}{l}\text { Self-completion questionnaire. } \\
\text { 1-year follow-up. }\end{array}$ & $\begin{array}{l}\text { Prevalence of prophylactic surgery preference } \\
\text { versus surveillance and analysis of factors } \\
\text { associated with those preferences. }\end{array}$ \\
\hline $\begin{array}{l}\text { Kurian et al. } \\
\text { (2005) }\end{array}$ & $\begin{array}{l}43 \text { women with high risk for } \\
\text { ovarian and breast cancer }\end{array}$ & $\begin{array}{l}\text { Self-completion questionnaire. } \\
\text { 1-year follow-up. }\end{array}$ & $\begin{array}{l}\text { Tolerance toward risk-reducing strategies and } \\
\text { change of attitude toward prophylactic mastectomy. }\end{array}$ \\
\hline $\begin{array}{l}\text { Philips et al. } \\
\text { (2006) }\end{array}$ & $\begin{array}{l}142 \text { carriers of BRCA } 1 / 2 \\
\text { mutation }\end{array}$ & $\begin{array}{l}\text { Self-completion questionnaire. } \\
3 \text { years follow-up. }\end{array}$ & Prevalence of risk-reduction decisions. \\
\hline
\end{tabular}

\subsection{Choosing Prophylactic Mastectomy (PM)}

For women regarded as at high-risk of developing breast cancer and ovarian cancer, due to the existence or strong probability of being carriers of a BRCA mutation based on family history, the decision for PM ranged between $11 \%$ and $15 \%$. Uyei et al. (2006), in a retrospective study with 554 women at risk, who underwent genetic testing for BRCA mutations, found a percentage of $15 \%$ who decided solely for PM, 5\% who decided solely for Prophylactic Oophorectomy (OP) and percentages of $4 \%$ and $9.4 \%$ regarding women who decided for both types of surgeries. In this study, the majority of women decided for surveillance. This option increases when women are non-carriers of BRCA mutations. This trend is in line with the fact that genetic positive results often rep- 
resent a milestone in women's decision for PM. Ray et al. [18] also found that $11 \%$ of women in their sample decided for PM. However, this study was conducted with a small sample (62 women), wherein not all women underwent testing for BRCA mutations. Antill et al. [19] conducted a study with women at high-risk for breast and ovarian cancer, and found a proportion of $4.4 \%$ women deciding for PM interventions (95\% CI 1.9 - 8.3).

When considering only women with BRCA $1 / 2$ mutation the prevalence of the decisions made are slightly altered. Stuckey et al. [20], in a retrospective study of 90 women with BRCA mutation, found that $51 \%$ of these women (33\% for BRCA 1 mutation carriers and 67\% for BRCA 2 mutation) had some kind of prophylactic surgery. Among these, 28\% underwent PM and $85 \%$ underwent PO. Studies show that in a smaller group of women at risk (BRCA mutation carriers), the frequency of decision for both PM and PO increases significantly, and in some studies this frequency is even higher than the adoption of surveillance methods. Metcalfe et al. [21], using the same type of sample and for 110 months, observed that $27.2 \%$ of women underwent PM, $66.7 \%$ decided for PO, 21\% decided for tamoxifen, and 23\% for surveillance methods. Another study also evaluated the long-term (10 years) decisions of women with BRCA mutations from the moment that they have been genetically tested, finding higher values of decision for PM (50\% underwent PM) [22].

Results show that in all studies including carriers of BRCA mutations, PM is the less frequent intervention measure adopted comparing with PO [23,24].

It seems, then, that the decision for PM increases in women with BRCA mutations; however, there is a percentage of women that decide for this type of intervenetion without being mutation carriers or even, as some studies refer, without having been tested. Ray et al. [18] found that $37 \%$ of women who underwent PM were not tested for BRCA mutations, suggesting that other factors influence the decision-making process. However, in other study with a small sample of women carrying BRCA mutations, all 7 women underwent PO, while 5 (71\%) underwent PM. Among the women who were not genetically tested, yet presenting a risk higher than $10 \%$ of having a BRCA mutation, 26\% underwent PM, while 32\% decided for PO [25]. Rueth et al. [26] conducted a study with a 71 women sample that underwent PM; among these, only 25 (35.2\%) had pre-surgery BRCA testing. Thus, we can posit that in spite of the fact that PM seems influenced by BRCA mutation status, there are some women that perform this intervention without having, or without even knowing whether they have the mutations.

Some studies focused on whether the decision for PM remained stable over time, especially if women changed their opinion after they found out that they were BRCA mutation carriers. Van djik et al. [27] found that before testing for genetic BRCA mutations, 25 of 77 women carrying the mutation intended to perform PM and, after a period of 9 months, 19 women had undergone the intervention. Hoogerburg et al. [28] found that among the women who intended to undergo PM before genetic results, between $66 \%$ and $89 \%$ (the variation is dependent on the coexistence of false positive results in MRI surveillance) performed PM at an average period of 2 years post-testing, while only $11 \%$ to $15 \%$ of women who initially had intentions to adopt the strategy of surveillance for risk reduction, conducted PM. In a study by Kurian et al. [29], the majority of patients (85\% (CI 68.9\% - 95.1\%)) maintained their attitude against adopting PM interventions or were even more decided not to undergo this intervention, one year after the genetic tests. Thus, it appears that the decision for PM as well as the decision for not being submitted to a PM intervention remains stable over time and, in many cases, it seems to be determined before knowing the results from BRCA-testing.

The average age of women who undergo mastectomy interventions was quite variable in the analysed studies; the age range was between 37 and 46 years of age, the majority had children and were married [18-30]. Women with a history of prior breast cancer are more likely to do prophylactic surgery instead of surveillance $(p=0.003)$ [20]. When comparing women with the BRCA mutation with those not tested, the later were older when they were operated (39.1 versus 49.2 years, $\mathrm{p}<0.001$ ), had more previous biopsies and mammograms. Among the untested, the most prevalent reasons for surgery were a family history of breast cancer (45.6\%), Ductal carcinoma in si$t u$ or atypical hyperplasia (34.8\%), or even just to reduce the risk and the anxiety of getting cancer in the future (19.6\%) [26].

\subsection{Decision-Making Factors}

The study of the reasons for the decision toward PM follows two approaches: 1) the analysis of studies that aim to find significant associations between PM and other possible factors influencing the decision-making process, and 2) the analysis of qualitative studies that, through a process of content analysis, aim to describe the perceptions of women included in their samples.

As it was mentioned above, the women's knowledge about being or not a BRCA mutation carrier is an important factor in the decision-making process toward PM, although not the only one. For Ray et al. [18], the most influential factors in the decision for prophylactic surgery were the results of genetic testing for BRCA mutations followed by family history of cancer. These authors state, alike Mcquiter et al. [31], that the genetic result may be seen as "a pivotal point" (p. 313) in the decision. Uyei et al. [30] also establish the association between BRCA 
mutation and prophylactic surgery (OR, 5.96, 95\% CI 2.74 - 12.97), in contrast to the negative association of PM with surveillance strategies (OR 0.22, 95\% CI 12:13 $-0.37)$.

One of the major factors influencing decision-making for PM, which is highlighted in some studies [18,19, 23,32], is the family history of breast cancer and ovarian cancer. According to Metcalf et al. [33], among the carriers of BRCA $1 / 2$, family history predicts the choice for $\mathrm{PM}$ or $\mathrm{PO}$ as a strategy for reducing cancer risk, concluding that women with sisters with breast cancer are more likely to perform PM than those without sisters with breast cancer $(\mathrm{OR}=2.4, \mathrm{p}=0.003)$. Antill et al. [19] also found a significant association between the PM and the number of first degree relatives with breast cancer ( $\mathrm{p}$ $=0.025$ ).

Parity also seems to be a factor associated with the choice of PM. Friebel et al. [23], suggest that parity and family history of ovarian cancer are predictors of decision toward PM in carriers of BRCA 1; the authors also found that tobacco use and family history of ovarian cancer are predictors of decision for PM in women with BRCA 2. Skytte et al. [22] also reported that age and having children also influence the decision for prophylactic surgery.

Besides Skytte et al. [22], Landsbergen et al. [34] also report the age of the most influential variable in the decision toward PM. These authors found that younger age and preference for PM prior to genetic testing are the stronger predictors of PM $(\mathrm{R} 2=0.57)$. In what concerns prior preference for PM, other authors [27-29] also refer to the stability strong determination of women's decisions regarding strategies to reduce risk of breast and ovarian cancer, but more specifically regarding prophylactic surgery. This issue is seen as the most predictive variable of the process of decision-making.

From the point of view of the women, which is the second approach for data analysis adopted in this review, and aiming to better understand their perceptions of the reasons for the decision, rejection or postponement of $\mathrm{PM}$, other variables stand out. The preoccupation with body image and sexuality are factors contributing for rejection of PM [35]: in a study with 18 women with BRCA mutations who were interviewed, the majority (12) underline as negative aspects of PM the impact on physical appearance/physical functioning (scarring, mutilation, period of recovery) and on body image [36]. In the sample of the study conducted by Staton et al. [37], concerns with appearance and preoccupation with sexuality were the second most frequently mentioned factors. Other rejection or postponement factors are concerns about the surgery, not only in relation to the recovery process, such as possible physical complications, but also the perception of the irreversibility of the act [18]. In the same stu- dy, other reasons cited for rejection/deferment were the feeling of not being "the right time in life" (p. 482) and the fear of "early menopause" (p. 482) (the latter more on the decision for PO). In the Tan et al. [38] study, the uncertainty about the decision (23\%) and the need for more information (23\%) were the main reasons for the postponement of the PM.

Howard et al. [39] describe some characteristics that a woman has into account regarding the definition of the "right time" for the MP's decision: when it fits in her life, when she had enough time to think about the decision, when she feels emotionally ready (when she resolves the inner conflict of being a BRCA mutation carrier), when all conflicts are resolved when they do not feel there are better options that the health system allows. In the van Dijk et al. [27] study, anticipating feelings of regret in the case of hypothetical breast cancer is strongly correlated with the preference for mastectomy compared with the preference for surveillance, in women with BRCA mutations ( $\mathrm{OR}=28.10, \mathrm{P}<0.001)$ and, therefore, it is a major factor influencing decision making. In Tan et al. [38], the main reasons for PM are: anxiety and risk of cancer reduction (56\%), avoiding the repetition of familial cancer (46\%), the feeling of responsibility for the family, husband and children (32\%) and lack of confidence in detection methods (23\%). Other authors identify the reduction of anxiety related with cancer as the most decisive factor in the decision-making process for PM [3941]. In Litton et al. [42] there is even a significant difference $(P=0.001)$ regarding the feeling that the $P M$ is the only way to reduce preoccupation, when comparing BRCA mutation carriers and non-carriers $(64.7 \%$ and $34.4 \%$, respectively).

Concerning the effects of PM on anxiety caused by cancer risk (one of the main reasons for undergoing PM), it is observed that women who decided for PM have lower estimates of their risk for breast cancer $(\mathrm{P}=0.052)$ [19], and total anxiety seems to decrease in the first year after PM ( $\mathrm{P}=0.02)$, but it did not significantly decreased in those who did not undergo surgery [43].

\section{Discussion}

An important methodological issue must be highlighted in our study, concerning the fact that no randomizedcontrol studies were found. For this reason, results had to be interpreted qualitatively, which does not enable the identification of effect sizes for the associations and differences suggested in the results section.

The decision for the most appropriate risk reduction strategy is not a straightforward process. The impact of strategies to reduce the risk of cancer and promote survival rate and quality of life are key criteria for a good decision-making. There is no single strategy that can meet all the expectations and requirements of an indivi- 
dual woman [7]. Thus, the decision for PM, as stated by the NCCN guidelines, is of a process to be discussed with the physician who will have to take into account informative aspects of surgery, risk calculation and degree of protection, as well as a careful approach to the woman's psychological well-being, with regards to her expectations, preferences, fears and concerns.

In this review we found that, on the one hand, the analysed studies found differences between women carrying BRCA mutations and non-carriers regarding the decision for PM, and the later decide for surveillance as a preventive strategy more often. Also, we found that BRCA mutation seems to influence the decision for prophylactic surgery, with more women choosing to undergo the surgery, even when compared to those at risk for breast cancer (those with family history, risk of more than $10 \%$ of being BRCA mutation carriers). The percentage of decision for PM tends to be lower than the percentage of decision for PO, in BRCA positive women. The decision for PM seems to be stable over time, even with the introduction of variables such as results of genetic tests.

Several authors state the need to establish "the right time" for the decision. Our study suggests that there are associations that involve socio-demographic data and family history; in fact, according to the review conducted, there seems to be associations between BRCA mutation status, age, parity and number of relatives with cancer. Other studies confirm these results, referring to the evidence of the influence of parity, BRCA mutation status and number of relatives with cancer in the decision for prophylactic surgery [35,44].

In the data reviewed and in our experience, BRCA mutation carriers often decide for PM based not only on the mutation status but also on their family history. For example, a women that has experienced deaths from cancer in young family members and has witnessed several cancer cases in her family is more likely to opt for PM, this apparently solely emotional choice can be clinically justified by different penetrance, which is difficult to quantify for an individual family.

Women refer anxiety regarding the risk of cancer as the main drive for the decision, leading them to anticipate feelings of regret, and the feeling that the PM and PO are the only ways to reduce their concerns in relation to their high percentage of risk. These results are in line with Howard et al. [35]: "The psychological consequences of perceived cancer risk, and cancer related distress, anxiety and worry also appear to be influential in risk-reducing surgery decisions” (p. 2).

The initial concerns and anxiety, seem to find real relief with PM, and these results are supported by previous reviews indicating that the majority of studies exploring the psychological impact of PM showed that women who chose this strategy are satisfied with their decision, de- creased their anxiety regarding the risk of cancer and experience less psychological difficulties [45].

However, and due to the fact that PM is an irreversible intervention, the decision is influenced by other important factors, particularly the ones related with body image and sexuality, which require from the physician a careful but thorough approach in information providing, but also in addressing fears and concerns, whether these are real or imagined, ensuring that they support woman is finding "the right time", in the most freely and informed way as possible $[35,45]$.

\section{Conclusions}

In our experience, counseling risk reducing strategies in BRCA mutations carriers or high-risk individuals without identified mutations, all women want a clear plan and some may need a surgery.

We generally do not counsel on PM before forming a family and childbearing. We are totally supportive and implement imaging and chemoprevention strategies for all our universe of at-risk individuals. However, a subgroup of women are not serene without prophylactic surgery. We start by proposing PO and in a stepwise approach we finally propose PM. Because of our gradual approach and complicity through years of counselling, a given patient we seldom have 1) a refusal of PM 2) a regret after PM. We maintain that PM is useful and effective but patient selection and close physician-patient interaction the key for success.

\section{REFERENCES}

[1] J. C. Bailar and H. L. Gornik, “Cancer Undefeated,” The New England Journal of Medicine, Vol. 336, 1997, pp. 1569-1574. doi:10.1056/NEJM199705293362206

[2] J. I. Goldberg and P. I. Borgen, "Breast Cancer Susceptibility Testing: Past, Present and Future,” Expert Review of Anticancer Therapy, Vol. 6, 2006, pp. 1205-1214. doi:10.1586/14737140.6.8.1205

[3] W. D. Foulkes, "Inherited Susceptibility to Common Cancers,” The New England Journal of Medicine, Vol. 359, 2008, pp. 2143-2153. doi:10.1056/NEJMra0802968

[4] Y. Miki, J. Swensen, D. Shattuck-Eidens, P. A. Futreal, K. Harshman, S. Tavtigian, et al., "A Strong Candidate for the Breast and Ovarian Cancer Susceptibility Gene BRCA1,” Science, Vol. 266, 1994, pp. 66-71. doi:10.1126/science.7545954

[5] R. Wooster, G. Bignell, J. Lancaster, S. Swift, S. Seal, J. Mangion, et al., "Identification of the Breast Cancer Susceptibility Gene BRCA2,” Nature, Vol. 378, 1995, pp. 789-792. doi:10.1038/378789a0

[6] F. Wang, Q. Fang, Z. Ge, N. Yu, S. Xu and X. Fan, “Common BRCA1 and BRCA2 Mutations in Breast Cancer Families: A Meta-Analysis from Systematic Review," Molecular Biology Reports, Vol. 39, 2012, pp. 2109-2118. 


\section{doi:10.1007/s11033-011-0958-0}

[7] M. Salhab, S. Bismohun and K. Mokbel, "Risk-Reducing Strategies for Women Carrying BRCA1/2 Mutations with a Focus on Prophylactic Surgery,” BMC Women's Health, Vol. 10, 2010, p. 28. doi:10.1186/1472-6874-10-28

[8] G. Rennert, S. Bisland-Naggan, O. Barnett-Griness, N. Bar-Joseph, S. Zhang, H. S. Rennert, et al., "Clinical Outcomes of Breast Cancer in Carriers of BRCA1 and BRCA2 Mutations," The New England Journal of Medicine, Vol. 357, 2007, pp. 115-123. doi:10.1056/NEJMoa070608

[9] S. Chen and G. Parmigiani, "Meta-Analysis of BRCA1 and BRCA2 Penetrance,” Journal of Clinical Oncology: Official Journal of the American Society of Clinical Oncology, Vol. 25, 2007, pp. 1329-1333.

[10] M. J. Bermejo-Perez, S. Marquez-Calderon and A. LlanosMendez, "Effectiveness of Preventive Interventions in BRCA1/2 Gene Mutation Carriers: A Systematic Review," International Journal of Cancer, Vol. 121, 2007, pp. 225231.

[11] N. Petrucelli, M. B. Daly and G. L. Feldman, "BRCA1 and BRCA2 Hereditary Breast and Ovarian Cancer,” In: R. A. Pagon, T. D. Bird, C. R. Dolan, K. Stephens and M. P. Adam, Eds., Gene Reviews, Seattle, 1993.

[12] D. M. van der Kolk, G. H. de Bock, B. K. Leegte, M. Schaapveld, M. J. Mourits, J. de Vries, et al., "Penetrance of Breast Cancer, Ovarian Cancer and Contralateral Breast Cancer in BRCA1 and BRCA2 Families: High Cancer Incidence at Older Age," Breast Cancer Research and Treatment, Vol. 124, 2010, pp. 643-651. doi:10.1007/s10549-010-0805-3

[13] E. H. Lee, S. K. Park, B. Park, S. W. Kim, M. H. Lee, S. H. Ahn, et al., "Effect of BRCA1/2 Mutation on ShortTerm and Long-Term Breast Cancer Survival: A Systematic Review and Meta-Analysis,” Breast Cancer Research and Treatment, Vol. 122, 2010, pp. 11-25. doi:10.1007/s10549-010-0859-2

[14] National Comprehensive Cancer Network. http://www.cancerresearchuk.org/cancer-info/cancerstats/ types/lung/

[15] A. Subramanian, M. Salhab and K. Mokbel, "Oestrogen Producing Enzymes and Mammary Carcinogenesis: A Review,” Breast Cancer Research and Treatment, Vol. 111, 2008, pp. 191-202. doi:10.1007/s10549-007-9788-0

[16] B. Fisher, J. P. Costantino, D. L. Wickerham, C. K. Redmond, M. Kavanah, W. M. Cronin, et al., "Tamoxifen for Prevention of Breast Cancer: Report of the National Surgical Adjuvant Breast and Bowel Project P-1 Study," Journal of the National Cancer Institute, Vol. 90, 1998, pp. 1371-1388. doi:10.1093/jnci/90.18.1371

[17] http://www.ibis-trials.org

[18] J. A. Ray, L. J. Loescher and M. Brewer, "Risk-Reduction Surgery Decisions in High-Risk Women Seen for Genetic Counseling," Journal of Genetic Counseling, Vol. 14, 2005, pp. 473-484. doi:10.1007/s10897-005-5833-5

[19] Y. Antill, J. Reynolds, M. A. Young, J. Kirk, K. Tucker, T. Bogtstra, et al., "Risk-Reducing Surgery in Women with Familial Susceptibility for Breast and/or Ovarian Cancer,” European Journal of Cancer, Vol. 42, 2006, pp. 621-628. doi:10.1016/j.ejca.2005.11.020

[20] A. Stuckey, D. Dizon, J. Scalia Wilbur, J. Kent, T. TejadaBerges, J. Gass, et al., "Clinical Characteristics and Choices Regarding Risk-Reducing Surgery in BRCA Mutation Carriers," Gynecologic and Obstetric Investigation, Vol. 69, 2010, pp. 270-273. doi:10.1159/000276573

[21] K. A. Metcalfe, C. Snyder, J. Seidel, D. Hanna, H. T. Lynch and S. Narod, "The Use of Preventive Measures among Healthy Women Who Carry a BRCA1 or BRCA2 Mutation,” Familial Cancer, Vol. 4, No. 2, 2005, pp. 97-103. doi:10.1007/s10689-005-4215-3

[22] A. B. Skytte, A. M. Gerdes, M. K. Andersen, L. Sunde, K. Brondum-Nielsen, M. Waldstrom, et al., "Risk-Reducing Mastectomy and Salpingo-Oophorectomy in Unaffected BRCA Mutation Carriers: Uptake and Timing," Clinical Genetics, Vol. 77, 2010, pp. 342-349. doi:10.1111/j.1399-0004.2009.01329.x

[23] T. M. Friebel, S. M. Domchek, S. L. Neuhausen, T. Wagner, D. G. Evans, C. Isaacs, et al., "Bilateral Prophylactic Oophorectomy and Bilateral Prophylactic Mastectomy in a Prospective Cohort of Unaffected BRCA1 and BRCA2 Mutation Carriers,” Clinical Breast Cancer, Vol. 7, 2007, pp. 875-882. doi:10.3816/CBC.2007.n.053

[24] A. Kwong, C. H. Wong, C. Shea, D. T. Suen and C. L. Choi, "Choice of Management of Southern Chinese BRCA Mutation Carriers,” World Journal of Surgery, Vol. 34, 2010, pp. 1416-1426. doi:10.1007/s00268-010-0477-5

[25] D. Morgan, H. Sylvester, F. L. Lucas and S. Miesfeldt, "Cancer Prevention and Screening Practices among Women at Risk for Hereditary Breast and Ovarian Cancer after Genetic Counseling in the Community Setting," Familial Cancer, Vol. 8, 2009, pp. 277-287. doi:10.1007/s10689-009-9242-Z

[26] N. M. Rueth, M. McMahon, A. K. Arrington, K. Swenson, J. Leach and T. M. Tuttle, "Preoperative Risk Assessment among Women Undergoing Bilateral Prophylactic Mastectomy for Cancer Risk Reduction,” Annals of Surgical Oncology, Vol. 18, 2011, pp. 2515-2520. doi:10.1245/s10434-011-1642-2

[27] S. van Dijk, M. S. van Roosmalen, W. Otten and P. F. Stalmeier, "Decision Making Regarding Prophylactic Mastectomy: Stability of Preferences and the Impact of Anticipated Feelings of Regret,” Journal of Clinical Oncology: Official Journal of the American Society of Clinical Oncology, Vol. 26, 2008, pp. 2358-2363.

[28] N. Hoogerbrugge, Y. J. Kamm, P. Bult, K. M. Landsbergen, E. M. Bongers, H. G. Brunner, et al., "The Impact of a False-Positive MRI on the Choice for Mastectomy in BRCA Mutation Carriers Is Limited," Annals of Oncology: Official Journal of the European Society for Medical Oncology/ESMO, Vol. 19, 2008, pp. 655-659.

[29] A. W. Kurian, A. R. Hartman, M. A. Mills, J. M. Ford, B. L. Daniel and S. K. Plevritis, "Opinions of Women with High Inherited Breast Cancer Risk about Prophylactic Mastectomy: An Initial Evaluation from a Screening Trial including Magnetic Resonance Imaging and Ductal Lav- 
age," Health Expectations: An International Journal of Public Participation in Health Care and Health Policy, Vol. 8, 2005, pp. 221-233.

[30] A. Uyei, S. K. Peterson, J. Erlichman, K. Broglio, S. Yekell, K. Schmeler, et al., "Association between Clinical Characteristics and Risk-Reduction Interventions in Women Who Underwent BRCA1 and BRCA2 Testing: A Single-Institution Study,” Cancer, Vol. 107, 2006, pp. 27452751. doi:10.1002/cncr.22352

[31] M. McQuirter, L. L. Castiglia, C. G. Loiselle and N. Wong, "Decision-Making Process of Women Carrying a BRCA1 or BRCA2 Mutation Who Have Chosen Prophylactic Mastectomy," Oncology Nursing Forum, Vol. 37, 2010, pp. 313-320. doi:10.1188/10.ONF.313-320

[32] E. K. Bancroft, I. Locke, A. Ardern-Jones, L. D’Mello, K. McReynolds, F. Lennard, et al., "The Carrier Clinic: An Evaluation of a Novel Clinic Dedicated to the Follow-Up of BRCA1 and BRCA2 Carriers-Implications for Oncogenetics Practice," Journal of Medical Genetics, Vol. 47, 2010, pp. 486-491. doi:10.1136/jmg.2009.072728

[33] K. A. Metcalfe, W. D. Foulkes, C. Kim-Sing, P. Ainsworth, B. Rosen, S. Armel, et al., "Family History as a Predictor of Uptake of Cancer Preventive Procedures by Women with a BRCA1 or BRCA2 Mutation,” Clinical Genetics, Vol. 73, 2008, pp. 474-479. doi:10.1111/j.1399-0004.2008.00988.X

[34] K. M. Landsbergen, J. B. Prins, Y. J. Kamm, H. G. Brunner and N. Hoogerbrugge, "Female BRCA Mutation Carriers with a Preference for Prophylactic Mastectomy Are More Likely to Participate an Educational-Support Group and to Proceed with the Preferred Intervention within 2 Years,” Familial Cancer, Vol. 9, 2010, pp. 213-220. doi:10.1007/s10689-009-9311-3

[35] A. F. Howard, L. G. Balneaves, J. L. Bottorff and P. Rodney, "Preserving the Self: The Process of Decision Making about Hereditary Breast Cancer and Ovarian Cancer Risk Reduction,” Qualitative Health Research, Vol. 21, 2011, pp. 502-519. doi:10.1177/1049732310387798

[36] E. Claes, G. Evers-Kiebooms, M. Decruyenaere, L. Denayer, A. Boogaerts, K. Philippe, et al., "Surveillance Behavior and Prophylactic Surgery after Predictive Testing for Hereditary Breast/Ovarian Cancer,” Behavioral medicine, Vol. 31, No. 3, 2005, pp. 93-105. doi:10.3200/BMED.31.3.93-106

[37] A. D. Staton, A. W. Kurian, K. Cobb, M. A. Mills and J. M. Ford, "Cancer Risk Reduction and Reproductive Concerns in Female BRCA1/2 Mutation Carriers,” Familial cancer, Vol. 7, No. 2, 2008, pp. 179-186. doi:10.1007/s10689-007-9171-7

[38] M. B. Tan, E. M. Bleiker, M. B. Menke-Pluymers, A. R. Van Gool, S. van Dooren, B. N. Van Geel, et al., "Standard Psychological Consultations and Follow up for Women at Increased Risk of Hereditary Breast Cancer Considering Prophylactic Mastectomy,” Hereditary Cancer in Clinical Practice, Vol. 7, No. , 2009, p. 6.

[39] A. F. Howard, J. L. Bottorff, L. G. Balneaves and C. Kim-Sing, "Women's Constructions of the 'Right Time' to Consider Decisions About Risk-Reducing Mastectomy and Risk-Reducing Oophorectomy," BMC Women's Health, Vol. 10, No. , 2010, p. 24. doi:10.1186/1472-6874-10-24

[40] C. Julian-Reynier, J. Mancini, E. Mouret-Fourme, M. Gauthier-Villars, V. Bonadona, P. Berthet, et al., "Cancer Risk Management Strategies and Perceptions of Unaffected Women 5 Years after Predictive Genetic Testing for BRCA1/2 Mutations," European Journal of Human Genetics, Vol. 19, No. , 2011, pp. 500-506. doi:10.1038/ejhg.2010.241

[41] E. Dagan and H. Goldblatt, "The Twilight Zone between Health and Sickness: A Qualitative Exploration with Asymptomatic BRCA1 and 2 Mutation Carriers,” Women \& Health, Vol. 49, No. 4, 2009, pp. 263-279. doi:10.1080/03630240903158321

[42] J. K. Litton, S. N. Westin, K. Ready, C. C. Sun, S. K. Peterson, F. Meric-Bernstam, et al., "Perception of Screening and Risk Reduction Surgeries in Patients Tested for a BRCA Deleterious Mutation,” Cancer, Vol. 115, No. 8, 2009, pp.1598-1604. doi:10.1002/cncr.24199

[43] K. A. Metcalfe, N. Mian, M. Enmore, A. Poll, M. Llacuachaqui, S. Nanda, et al., "Long-Term Follow-Up of Jewish Women with a BRCA1 and BRCA2 Mutation Who Underwent Population Genetic Screening," Breast Cancer Research and Treatment, Vol. 133, No. 2, 2012, pp. 735-740. doi:10.1007/s10549-011-1941-0

[44] R. L. Croshaw, M. L. Marshall, T. L. Williams, K. M. Erb and T. B. Julian, "Prophylactic and Therapeutic Breast Conservation in BRCA1/2 Mutation Carriers,” International Journal of Breast Cancer, Vol. 2011, No. 2011, 2011, Article ID: 481563.

[45] D. C. Allain, K. Sweet and D. M. Agnese, "Management Options after Prophylactic Surgeries in Women with BRCA Mutations: A Review," Cancer Control: Journal of the Moffitt Cancer Center, Vol. 14, No. 4, 2007, pp. 330-337. 